\title{
Quality of Life among Medical Students in Tanta University, EGYPT
}

Mira M. Abu-elenin ${ }^{1 *}$, Walaa M. Shehata ${ }^{2}$

1,2 Public Health and Community Medicine Department, Faculty of Medicine, Tanta University, Egypt

\begin{abstract}
:
Background: The quality of life of medical students could be affected by many educational stressors and improving it may have a positive effect on their physical, mental health and their academic achievements. Objectives: To assess the quality of life (QOL) of medical students at Faculty of Medicine, Tanta University, at the six educational levels and the most important factors related to their quality of life. Methods: A cross sectional study was conducted on 431 medical students at Faculty of Medicine, Tanta University, Egypt, during the academic year 2016/2017. A multistage random sampling technique was performed. The WHO Quality of Life Health Survey- Short Form SF-36 was used. Results: Regarding Quality of Life SF-36; medical students had good quality mean score regarding the role emotional limitation domain $(85.9 \pm 28.8)$ and physical functioning domain $(66.1 \pm 22.9)$. There were no significant difference between the six grades regarding physical health component, the mental health component and the total quality of life scores. Lower quality of life score were confined to female students with rural background and lack of sleep and physical activity $(p<0.05)$. Conclusions: The medical students showed fair quality of life scores with the physical health component score lower than the mental one.
\end{abstract}

Keywords: Egypt, Medical students, Quality of life, Tanta.

Introduction: Medical schools are devoted to establish a learning environment to be competent and qualified physicians to promote and maintain society health. ${ }^{(1)}$ Therefore, their physical and emotional wellbeing have been always a subject of interest .The students' quality of life (QOL) is an indicator for their overall health status. ${ }^{(2)}$ It is assumed that medical students should have a better health status than general population, however, it is also a population that is constantly being exposed to a great number of stress, there are studies showing that medical students' mental health worsens during their study constrain. ${ }^{(3,4)}$

Medical students usually suffer an academic stress due to study and tough exams. Therefore, their academic achievement might be compromised, and their quality of life as well. Previous researches stated that quality of life is poor among medical students. ${ }^{(5,6)}$ The World Health Organization has defined (QOL) as the physical, psychological and social welfare which is understood by Individuals' perception of their position in the context of culture and value systems in which they live and in relation to their goals, expectations, standards and concerns. ${ }^{(7)}$ Evaluation of medical students' health status may help to figure out measures to improve the mental health and QQL of students at risk. ${ }^{(8)}$

Overall medical students are of promoting position because of their role in the future of their communities. The wellbeing of medical students and the quality of their 
education have an increasing trend over the past decades. ${ }^{(2)}$ This study aimed to assess the quality of life (QOL) of medical students at Faculty of Medicine, Tanta University, at the six educational levels and the most important factors related to their quality of life.

Methods: A cross sectional study was conducted on medical students in Faculty of Medicine, Tanta University, Egypt, during the academic year 2016/2017. The sample size was measured using EPI info program (Centers for Disease Control and Prevention (CDC), Atlanta, Georgia, USA). The following criteria were considered for sample size calculation: confidence interval 95\%, power of the study $80 \%$ and the level of good quality of life among medical students expected to be detected is $50 \%$ with a range of error $5 \%$. Reviewing number of students in different academic levels during academic year 2016/2017 has been done [Year (1) 830, Year (2) 700, Year (3) 650, Year (4)625, Year (5) 640, and Year (6) 627].

A multistage random sampling technique was performed. Each academic year was divided into a four sections, one section from each grade was selected randomly. The students in selected section were recruited to reach the calculated study sample $(n=470)$. Four hundred thirty one (431) students were included; the non response rate was $9 \%$.
Students were invited to fill in a selfadministered questionnaire comprising: the WHO Quality of Life SF-36 v2 Health Survey, information about socio-demographic characteristics.

Data were collected during class intervals or after classes. Student participation was voluntary. Whenever a student returned a questionnaire with a blank field, he/she was immediately invited to provide the information that was missing. The questions in the SF-36 ask the students about healthrelated quality of life matters that have occurred in the last four-week period. Data collected from the SF-36 form were used in the construction of eight domains: physical functioning, role limitations due to physical problems, bodily pain, general health perceptions, vitality, social functioning, role limitations due to emotional problems, and mental health. The eight multi-item scales were aggregated into Physical Component Summary and Mental Component Summary scores.

Items of 36-SF responses are ranged from 1 (stands for poor response) to 5 (for positive response). Then all questions are scored on a scale from 0 to 100 , with 100 representing the highest level of functioning possible. The scores from those questions that address each specific area of functional health domain are 
then averaged together, for a final score within each of the 8 dimensions measured. This procedure transforms scores to a mean of 50 and standard deviation of 10 . Higher scores represent better health-related quality of life.

Ethical considerations: Ethical approval for the study was granted Internal Review Board of Tanta Faculty of Medicine; verbal consents were obtained from students to participate in the study after explaining the nature and benefits of it.

Statistical analysis: One-way analyses of variance compared the means of SF-36 domains and its component scores according to academic year. Independent sample t-test was used to compare physical component summary (PCS) and mental component summary (MCS) mean scores stratified according to relevant covariates Data was analyzed using SPSS program, version 21. Results: Out of 431 students from the six academic grades, 57.4\% aged 17-21 years and $42.6 \%$ aged 22-26 years. Girls constituted about three quarters of our sample $(75.6 \%)$. $72.8 \%$ were urban residents. More than half of them $(54.0 \%)$ don't practice any physical activity. Only $33.0 \%$ of them suffer from headache with more than two thirds of them $(68.6 \%)$ live with their families as demonstrated in Table (1). Regarding SF-36 domains; it was observed that the highest mean score was recorded for role emotional limitation domain followed by physical functioning domain as shown in Table (2).

On comparing physical health component scores, the mental health component and the total quality of life score between the six academic grades, no significant difference was found as shown in Table 3. Mental Component Summary mean score was significantly lower among female students, whom of rural residence and not living with their families. Both physical and Mental Component Summary mean scores were significantly lower between students suffering from lack of sleepiness, headaches, and who mentioned not to practice physical activity on regular basis (Table 4). SF-36 total score was found significantly high among males and in relation to urban background, practice of physical activity and good sleep $(\mathrm{P}<0.05)$.

Discussion: Medical students have experienced an academic stress compared with non-medical ones, as medical study has an impact on physical and mental health of students. $^{(9,10)}$ Due to the long duration of training, stressful academic demands, tough examinations, and exposure to stressful clinical situations. ${ }^{(11,12)}$ So, compared to other students, medical students are more susceptible to physical and mental stress, depression and anxiety and more liable to 
suffer from burning out. ${ }^{(9,13-15)}$ The researchers found that the highest mean score was recorded for role emotional functioning /limitation domain $(85.9 \pm 28.8)$ followed by physical functioning domain $(66.1 \pm 22.9)$ and the lowest score was in general health domain $(44.2 \pm 12.6)$.

These results were different from results of Lins et al.2015, who found that the highest mean score in physical functioning domain (86.5 \pm 16.3 ) followed by Bodily Pain (BP) domain (70.6 \pm 21.2$)$. While the lowest mean score was found in Vitality domain (50.0 \pm 20.1) ${ }^{(6)}$, these results are similar to results obtained by Domantay, 2014; the physical functioning domain (85.83 \pm 15.68$)$ and bodily pain domain $(69.20 \pm 21.74)$ are the highest but with role-emotional domain (51.36 $\pm 44.20)$ is the lowest. ${ }^{(11)}$ While Latas et al. 2014, found that the physical functioning domain recorded the highest mean score $(95.2$ \pm 9.89) followed by Role limitations due to physical health $(80.70 \pm 28.99)$ and the lowest score was in Energy/ fatigue domain $(55.60 \pm 18.91){ }^{(16)}$

Our results revealed that the mental component summary $(59.5 \pm 16.4)$ was higher than the physical one $(53.07 \pm 12.5)$ with total SF-36 score was $112.48 \pm 24.3$, this is may be attributed to lack of free time available for medical students in Egypt to do physical exercises to improve their physical health. These findings are in contrary with Latas et al. 2014, results who found that the physical component summary $(76.32 \pm 13.51)$ was higher than the mental one $(67.07 \pm 17.87)$ with lower total SF-36 score $(73.31 \pm 15.23) .{ }^{(16)}$ Our findings indicated that the mental component summary scores was higher than the physical scores in all the six medical grades, which is in contrary to results of Lins et al. 2015, who revealed that the physical scores were higher than the mental ones. ${ }^{(6)}$ This is might be due to the curricular and extra-curricular activities that must be achieved in different phases of the curriculum. Therefore students did not have a plenty of time to practice physical activity on regular basis.

On comparing physical and mental components score means among the six grades, we didn't found any significant difference. This is in accordance with Lins et al.2015, who found very weak correlation between the course year and SF-36 domains and component summaries, none of them reaching a P-value $<0.05$. $^{(6)}$ In the current study, the physical component summary mean scores were significantly lower $(\mathrm{P}<0.05$ or less) among those suffering from lack of sleepiness and who mentioned not to practice physical activity on regular basis and also lower among female students, those from 
rural areas, those suffering from headache and who didn't live with their families but without statistical significance. This could be due to lack of awareness of the importance of practicing regular physical activities.

This is quite similar to Lins et al. 2015, ${ }^{(6)}$ which revealed that physical component summary mean scores were significantly lower among those who complain of headaches, and those who did not report regular physical activity, but it is different from Latas et al.2014, ${ }^{(16)}$ who found that the significant predictors for the physical component in medical students were: male sex, younger age and higher grade year of studies. Additionally, the Mental Component Summary mean scores were significantly lower $\quad(\mathrm{P}<0.05)$ among female students, whom of rural residence, complaints of headaches, those who did not report regular physical activity and not living with their families. This is may be explained by the fact that females and those from rural residence may not be fully aware of the importance of improving their mental abilities through different resources.

These findings are in accordance with Lins et al. $2015,{ }^{(6)}$ results but with no statistically significance regarding except for sleepiness and physical activity, while Latas et al. 2014, ${ }^{(16)}$ showed that the significant predictors for the mental component were : male sex, younger age, higher grade year of studies and marital status. Regarding the total SF-36 score; Latas et al. 2014, found that the score was significantly affected in males, younger age and higher year of studies. ${ }^{(16)}$ While we found in addition to male sex, it was also significantly higher in those with urban background, practice of physical activity, good sleep and living with their families.

Study limitations: The results of the study cannot be extrapolated due to the sample was not representative to the students from different medical schools.

Conclusion: The medical students showed fair quality of life scores with the physical health component score lower than the mental one. Lower SF-36 scores of quality of life were confined to female students, those with rural background and lack of sleep and physical activity.

Conflict of interest: There is no conflict of interest.

\section{References:}

1. 1. Almalki SA, Almojali AB, AlothmanALS, Masuadi EM. Alaqeel MK: Burnout and its association with extracurricular activities among medical students in Saudi Arabia.International Journal of Medical Education. 2017; 8:144-150. 
2. Heidari MO, Majdzadeh RE, Pasalarand PA, Nedjat SO: Quality of life of medical students in Tehran University of Medical Sciences.Acta Medica Iranica, 2014;52 (5):390-399.

3. Tosevski DL, Milovancevic MP, Gajic SD: Personality and psy-chopathology of university students. Curr Opin Psychiatry, 2010; 23(1): 481̂52.

4. Carson AJ, Dias S, Johnston A, McLoughlin MA, O'Connor M, Robinson BL et al.,: Mental health in medical students. A case control study using the 60 item General Health Questionnaire. Scott Med J, 2000; 45(4): $115 \hat{\imath} 6$.

5. Dyrbye LN, Thomas MR, Power DV, Durning S, Moutier C, Massie FS Jr, Harper W, Eacker A. Burnout and serious thoughts of dropping out of medical school: a multi-institutional study. Acad Med, 2010; 85(1): 94î102.

6. Lins L, Carvalho FM, Menezes MS, Porto-Silva L, Damasceno H: Healthrelated quality of life of students from a private medical school in Brazil. Int J Med Educ, 2015;6:149-54.

7. WHOQOL Group. The World Health Organization Quality of Life assessment (WHOQOL): position paper from the World Health Organization. Soc Sci Med, 1995; 41(10):1403-9.
8. Paro HE, Morales NI, Silva CA, Rezende CH, Pinto RM, Morales RR et al.,: Healthrelated quality of life of medical students 2010. MEDICAL EDUCATION, 2010; 44: $227-235$.

9. Dyrbye LN, Thomas MR, Huschka MM, Lawson KL, Novotny PJ, Sloan JA et al.,: A multicenter study of burnout, depression, and quality of life in minority and nonminority US medical students. Mayo Clin Proc Nov, 2006; 81: 14351442.

10. Goldin SB, Wahi MM, Farooq OS, Borgman HA, Carpenter HL, Wiegand LR et al.,: Student quality-of-life declines during third year surgical clerkship. J Surg Res Nov, 2007; 143: 151-157.

11. Domantay JAA: Health-related quality of life of future physicians at a medical school in the Philippines: a cross-sectional study. SAGE Open, 2014: 1-9

12. Dyrbye LN, West CP, Satele D, Boone S, Tan L, Sloan J et al.,: Burnout among U.S. Medical students, residents, and early career physicians relative to the general U.S. Population. Acad Med., 2014; 89: 443-451.

13. Aktekin M, Karaman T, Senol YY, Erengin H, Akaydin M : Anxiety, depression and stressful life events among medical students: A prospective study in 
Antalya, Turkey. Med Educ, 2001; 35: 12-17.

14. Dyrbye LN, Thomas MR, Eacker A, Harper W, Massie FS Jr, Power DV et al.,: (2007) Race, ethnicity, and medical student well-being in the united states. Arch Intern Med, 2007; 167: 2103-2109.

15. Compton MT, Carrera J, Frank E: Stress and depressive symptoms/dysphoria among us medical students: Results from a large, nationally representative survey. J Nerv Ment Dis, 2008; 196: 891-897.

16. Latas M, Stojkovic T, Ralic T, Jovanović S, Spirić Z, Milovanović S : Medical students' health-related quality of life - A comparative study. Vojnosanit Pregl, 2014; 71(8): 751-756. . 
Table (1): Socio-demographic characteristics of studied students

\begin{tabular}{|c|c|c|}
\hline Socio-demographic characteristics & No. & $\%$ \\
\hline $\begin{array}{ll} & \text { Age: } \\
& 17-21 \text { years } \\
& 22-26 \text { years } \\
\end{array}$ & $\begin{array}{l}247 \\
184 \\
\end{array}$ & $\begin{array}{l}57.4 \% \\
42.6 \% \\
\end{array}$ \\
\hline $\begin{array}{ll} & \text { Sex: } \\
\text { - } & \text { Male } \\
\text { - } & \text { Female }\end{array}$ & $\begin{array}{l}105 \\
326\end{array}$ & $\begin{array}{l}24.4 \% \\
75.6 \%\end{array}$ \\
\hline $\begin{array}{l}\text { Residence: } \\
\text { - } \text { Rural } \\
\text { - Urban }\end{array}$ & $\begin{array}{l}117 \\
314\end{array}$ & $\begin{array}{l}27.1 \% \\
72.8 \%\end{array}$ \\
\hline $\begin{array}{l}\text { Physical activity: } \\
\text { - No } \\
\text { - } \text { Yes }\end{array}$ & $\begin{array}{l}233 \\
198\end{array}$ & $\begin{array}{l}54.0 \% \\
46.0 \%\end{array}$ \\
\hline $\begin{array}{ll} & \text { Sleepiness } \\
\text { - } & \text { No } \\
\text { - } & \text { Yes } \\
\end{array}$ & $\begin{array}{l}234 \\
197 \\
\end{array}$ & $\begin{array}{l}54.3 \% \\
45.7 \% \\
\end{array}$ \\
\hline $\begin{array}{ll} & \text { Headache } \\
\text { - } & \text { No } \\
\text { - } & \text { Yes }\end{array}$ & $\begin{array}{l}289 \\
142\end{array}$ & $\begin{array}{l}67.0 \% \\
33.0 \%\end{array}$ \\
\hline $\begin{array}{ll} & \text { Live with family } \\
\text { - } & \text { No } \\
\text { - Yes }\end{array}$ & $\begin{array}{l}135 \\
296\end{array}$ & $\begin{array}{l}31.4 \% \\
68.6 \%\end{array}$ \\
\hline
\end{tabular}

Table (2): SF-36 domains of quality of life raw scores (mean \pm SD) among the studied students

\begin{tabular}{|l|l|l|}
\hline Domain & Mean scale \pm SD & Range \\
\hline - General Health & $44.2 \pm 12.6$ & $6-84$ \\
\hline - Physical Functioning (PF) & $66.1 \pm 22.9$ & $0-100$ \\
\hline - Role Physical (RP) & $50.9 \pm 18.8$ & $0-100$ \\
\hline - Bodily Pain (BP) & $51.1 \pm 22.5$ & $0-100$ \\
\hline - Social Functioning (SF) & $50.9 \pm 19.7$ & $0-100$ \\
\hline - Emotional Wellbeing & $51.5 \pm 17.2$ & $0-100$ \\
\hline - Role Emotional -limit (RE) & $85.9 \pm 28.8$ & $0-100$ \\
\hline - Energy/Vitality & $49.5 \pm 15$ & $0-100$ \\
\hline - Physical Health Component Summary & 53.0724 .3 & $44.46-185.6$ \\
\hline - Mental Health Component Summary & $59.5 \pm 16.3$ & $6.25-103.96$ \\
\hline - Total SF-36 score & $112.4 \pm 24.3$ & $44-185$ \\
\hline
\end{tabular}


Table (3): SF-36 domains scores (mean \pm SD) of studied students according to their distribution in academic years

\begin{tabular}{|c|c|c|c|c|c|c|c|c|}
\hline Domain & $\begin{array}{c}1^{\text {st }} \text { year } \\
(n=68)\end{array}$ & $\begin{array}{c}2^{\text {nd }} \text { year } \\
(n=74)\end{array}$ & $\begin{array}{c}3^{\text {rd }} \text { year } \\
(n=74)\end{array}$ & $\begin{array}{c}4^{\text {th }} \text { year } \\
(n=73)\end{array}$ & $\begin{array}{c}5^{\text {th }} \text { year } \\
(n=71)\end{array}$ & $\begin{array}{c}6^{\text {th }} \text { year } \\
(n=71)\end{array}$ & $\mathbf{F}$ & $\begin{array}{c}\text { P- } \\
\text { value }\end{array}$ \\
\hline - General Health & $43.7 \pm 11$ & $45.6 \pm 12$ & $44.8 \pm 14.9$ & $43.3 \pm 11$ & $42 \pm 12.3$ & $45.6 \pm 13.8$ & 0.91 & 0.4 \\
\hline - $\quad$ Physical Functioning & $61.7 \pm 23.8$ & $69 \pm 21.4$ & $67.8 \pm 23.4$ & $63.2 \pm 21.1$ & $66.9 \pm 23$ & $67.6 \pm 24.7$ & 1.19 & 0.3 \\
\hline - Role Physical (RP) & $53.1 \pm 19.6$ & $48.9 \pm 14.6$ & $50.3 \pm 20.4$ & $49.2 \pm 18.4$ & $53 \pm 20.2$ & $50.8 \pm 19.5$ & 0.65 & 0.6 \\
\hline $\begin{array}{l}\text { - Emotional Well- } \\
\text { being }\end{array}$ & $53.6 \pm 14.8$ & $53.7 \pm 15.44$ & $49.5 \pm 19.6$ & $53.9 \pm 18.2$ & $47.1 \pm 18.8$ & $51.6 \pm 15.4$ & 1.8 & 0.09 \\
\hline $\begin{array}{l}\text { - Role Emotional -limit } \\
\text { (RE) }\end{array}$ & $89.4 \pm 24.7$ & $89.5 \pm 25.7$ & $82.5 \pm 32.7$ & $89.8 \pm 30.3$ & $78.5 \pm 31.4$ & $86 \pm 25.7$ & 0.8 & 0.4 \\
\hline - $\quad$ Social functioning & $49.8 \pm 16.3$ & $53.3 \pm 20.6$ & $46.11 \pm 21.5$ & $54.8 \pm 18.7$ & $48.7 \pm 20.8$ & $52.8 \pm 19.1$ & 1.12 & 0.3 \\
\hline - Bodily Pain & $46.5 \pm 20.2$ & $54.5 \pm 18.4$ & $53.2 \pm 24.3$ & $51.5 \pm 27.15$ & $50.8 \pm 19.6$ & $49.4 \pm 23.6$ & 2.2 & 0.07 \\
\hline - Energy/Vitality & $49.5 \pm 13.3$ & $51.8 \pm 13.4$ & $48.8 \pm 14.8$ & $49.4 \pm 14.1$ & $49.03 \pm 18$ & $48.15 \pm 16$ & 0.52 & 0.7 \\
\hline - PHCs & $51.2 \pm 12.1$ & $54.7 \pm 10.2$ & $54 \pm 13.2$ & $51.4 \pm 13.1$ & $53.3 \pm 12.2$ & $53.4 \pm 13.7$ & 0.8 & 0.4 \\
\hline - MHCs & $60.6 \pm 13.7$ & $62.1 \pm 14.5$ & $56.7 \pm 18.6$ & $62 \pm 16.5$ & $55.8 \pm 17.8$ & $59.6 \pm 15.6$ & 1.9 & 0.08 \\
\hline Total SF-36 score & $111.8 \pm 22$ & $116.7 \pm 20.1$ & $110.8 \pm 27.6$ & $113 \pm 23.2$ & $109.3 \pm 25.45$ & $113 \pm 26.4$ & 0.763 & 0.75 \\
\hline
\end{tabular}

F: Analysis of Variance (ANOVA) 
Table (4): SF-36 component summaries scores (mean \pm SD) according to covariates among studied students

\begin{tabular}{|c|c|c|c|c|c|c|c|c|c|c|}
\hline Covariate & No. & $\begin{array}{c}\text { Physical } \\
\text { Component } \\
\text { Summary } \\
\text { (PCS) }\end{array}$ & $\begin{array}{c}\text { t- } \\
\text { test }\end{array}$ & $\begin{array}{c}\text { P- } \\
\text { value }\end{array}$ & $\begin{array}{c}\text { Mental } \\
\text { Component } \\
\text { Summary } \\
\text { (MCS) }\end{array}$ & $\begin{array}{l}\text { t- } \\
\text { test }\end{array}$ & $\begin{array}{c}\text { P- } \\
\text { value }\end{array}$ & $\begin{array}{c}\text { Total SF- } \\
36 \text { score }\end{array}$ & $\begin{array}{c}\text { t- } \\
\text { test }\end{array}$ & P-value \\
\hline $\begin{array}{l}\text { Age: } \\
\text { - } \quad 17-21 \mathrm{Ys} \\
\text { - } \quad 22-26 \mathrm{Ys}\end{array}$ & $\begin{array}{l}247 \\
184\end{array}$ & $\begin{array}{l}53.1 \pm 12 \\
52.9 \pm 13\end{array}$ & 0.12 & 0.8 & $\begin{array}{l}59.6 \pm 16.1 \\
59.2 \pm 16.7\end{array}$ & 0.23 & 0.8 & $\begin{array}{c}112.6 \pm 23.8 \\
112.2 \pm 25\end{array}$ & 0.3 & 0.8 \\
\hline $\begin{array}{l}\text { Sex: } \\
\text { - } \quad \text { Male } \\
\text { - } \quad \text { Female }\end{array}$ & $\begin{array}{l}105 \\
326\end{array}$ & $\begin{array}{c}54.5 \pm 13.8 \\
52.5 \pm 12\end{array}$ & 1.3 & 0.17 & $\begin{array}{c}65.7 \pm 15.6 \\
57.5 \pm 16.11\end{array}$ & 4.5 & $0.0006^{*}$ & $\begin{array}{c}119.9 \pm 26.1 \\
110 \pm 23.2\end{array}$ & 3.66 & $0.0002 *$ \\
\hline $\begin{array}{l}\text { Residence: } \\
\text { - } \quad \text { Rural } \\
\text { - Urban } \\
\end{array}$ & $\begin{array}{l}117 \\
314\end{array}$ & $\begin{array}{l}55.7 \pm 14 \\
57 \pm 13.3\end{array}$ & 0.8 & 0.3 & $\begin{array}{c}53.16 \pm 12.3 \\
59.5 \pm 11.4\end{array}$ & 4.8 & $0.0001 *$ & $\begin{array}{c}108 \pm 21.3 \\
124.9 \pm 16.7\end{array}$ & 8.6 & $<0.0001^{*}$ \\
\hline $\begin{array}{l}\text { Physical } \\
\text { activity: } \\
\text { - No } \\
\text { - Yes }\end{array}$ & $\begin{array}{l}233 \\
198\end{array}$ & $\begin{array}{c}56.4 \pm 12.6 \\
63.814 .5\end{array}$ & 5.6 & $0.0001 *$ & $\begin{array}{c}57 \pm 12.5 \\
58.3 \pm 11.2\end{array}$ & 1.9 & $0.04 *$ & $\begin{array}{l}115.4 \pm 13.8 \\
121.2 \pm 33.2\end{array}$ & 2.4 & $0.01 *$ \\
\hline \begin{tabular}{ll}
\multicolumn{2}{l}{ Sleepiness } \\
- $\quad$ No \\
- Yes \\
\end{tabular} & $\begin{array}{l}234 \\
197\end{array}$ & $\begin{array}{l}52.3 \pm 6.1 \\
48.4 \pm 7.2\end{array}$ & 6.03 & $0.0001 *$ & $\begin{array}{c}54.7 \pm 11 \\
52.3 \pm 10.5\end{array}$ & 2.3 & $0.02 *$ & $\begin{array}{c}117 \pm 19.7 \\
123.8 \pm 20.6\end{array}$ & 3.5 & $0.0004 *$ \\
\hline $\begin{array}{l}\text { Headache } \\
\text { - No } \\
\text { - } \quad \text { Yes } \\
\end{array}$ & $\begin{array}{l}289 \\
142 \\
\end{array}$ & $\begin{array}{c}55.8 \pm 9.8 \\
54.3 \pm 10.4\end{array}$ & 1.5 & 0.12 & $\begin{array}{c}54.2 \pm 10.1 \\
51.7 \pm 9.3\end{array}$ & 2.4 & $0.013^{*}$ & $\begin{array}{c}124.3 \pm 21.8 \\
121 \pm 23.7\end{array}$ & 1.3 & 0.19 \\
\hline $\begin{array}{l}\text { Live with } \\
\text { family } \\
\text { - } \quad \text { No } \\
\text { - } \quad \text { Yes } \\
\end{array}$ & $\begin{array}{l}135 \\
296\end{array}$ & $\begin{array}{c}53.9 \pm 12.4 \\
54.4 \pm 11.3\end{array}$ & 0.4 & 0.6 & $\begin{array}{c}52 \pm 11.7 \\
54.8 \pm 10.4\end{array}$ & 2.3 & $0.017^{*}$ & $\begin{array}{l}137.9 \pm 26.5 \\
128.8 \pm 19.3\end{array}$ & 7.4 & $<0.0001 *$ \\
\hline
\end{tabular}

t-test: independent sample T test 


\section{الملخص العربي \\ جودة الحياة النوعية بين طلاب كلية الطب وجامعة طنطا, مصر}

مير ا ابو العينين-و لاء شيحاته

الخلفيه: يجب ان توفر كليات الطب بيئة تعليمية صحية لتخريج أطباء مؤهلين يمتلكون المعرفة والمهار ات و الكفاءات اللازمة لتعزيز صحة المجتمع. لذلك فأن صحتهم الجسدية والذهنية محل اهتمام بين الباحثين. جودة الحياة النوعية هي واحدة من المؤشرات الرئيسية للحالة الصحية العامة للفرد. من المفترض أن الحالة صحية بين طلاب كليات الطب البشرى أفضل نسبيًا عن يقية افراد المجتمع الاخرين ، ومع ذلك ، فإنهم يتعرضون باستمرار لكثير من الإجهاد البدنى والضغط النفسى ، هنالك دراسات تشير أن الصحة النفسية لطلاب كليات الطب تزداد سوءا أثناء در استهم ,حيث تتأثر جودة الحياة النوعية لاى طلاب كلية الطب بالعديد من عوامل الإجهاد العملية والمهنية و العلمية وتحسينها قد يكون له تأثير إيجابي على الصحة الجسدية والعقلية والإنجازات الأكاديمية للطلاب. الأهداف: تقييم جودة الحياة النوعية لدى طلاب الطب في كلية الطب البشرى، جامعة طنطا ، فى المستويات الأكاديمية الستة. طرق الاراسة والبحث : أجريت در اسة مقطعية مستعرضة بين 431 طالباً وطالبة بكلية الطب البشرى، جامعة طنطا بمصر ، خلال العام الدر اسي 2016/ 2017. تم إجر اء تقنية أخذ عينات عشوائية متعددة المر احل. نم استخدام نموذج الاستقصاء المسح SF-36 الخاص بجودة الحياة النوعية التابع لمنظمة الصحة العالمية.النتائج: تم تسجيل أعلى متوسط لجودة الحياة في المجال العاطفي(9585 × 8وو28) يليه مجال الأداء الوظيفي (1وـ66 9و22) مع عدم وجود فرق ملحوظ بين الصفوف الستة الاكاديمية.كما لوحظ انخفاض بموءشرات الصحة البدنية و الذهنية واجمالى جودة الحياة النوعية بين الطالبات عن الطلبة البنين، و الطلبة ساكنى المناطق الريفية,كذلك الذين يعانون من اضطربات في النوم و لا يمارسون اى أنشطة رياضية ـ الاستتتاجات: نستخلص من هذة الدراسة أن طلاب كلية الطب لديهم موءشرات متوسطة من جودة الحياة النوعية مع وجودأنخفاض ملحوظ بموءاثرات الصحة الجسدية عن الصحةالذهنية.التوصيات: توصى الدراسة بان تاخذ كليات الطب البشرى المزيد من الخطوات لتحقيق التوازن بين الدراسة الاكاديميه وتحسين صحة الطلاب البدنية والذهنية و النفسية. 